\title{
Efficacy and Baseline Sensitivity of Succinate-Dehydrogenase-Inhibitor Fungicides for Management of Colletotrichum Crown Rot of Strawberry
}

\author{
Michelle S. Oliveira, Leandro G. Cordova, and Natalia A. Peres ${ }^{\dagger}$ \\ Gulf Coast Research and Education Center, University of Florida, Wimauma, FL 33598
}

\begin{abstract}
The current management of Colletotrichum crown rot (CCR) of strawberry, caused by Colletotrichum gloeosporioides sensu lato, relies on the use of a few fungicide classes, particularly QoI fungicides. Since resistance to QoI fungicides has recently been detected, alternative fungicide groups are needed to control this disease. Our objective was to evaluate the efficacy of succinate-dehydrogenase-inhibitor (SDHI) fungicides in managing CCR. Five SDHI fungicides, fluopyram, isofetamid, penthiopyrad, fluxapyroxad, and benzovindiflupyr, were applied 2 days before or 1 day after inoculation of cultivar Strawberry Festival. SDHI

CCR management, i.e., thiophanate-methyl, pyraclostrobin, and captan. Benzovindiflupyr applied 1 day after inoculation was effective in reducing plant mortality and disease development. The baseline sensitivity of C. gloeosporioides isolates was determined in vitro using a spiral gradient dilution assay. The $\mathrm{EC}_{50}$ for benzovindiflupyr and penthiopyrad varied from 0.08 to 1.11 and 0.45 to $3.17 \mu \mathrm{g} / \mathrm{ml}$, respectively, whereas the other SDHI fungicides did not inhibit fungal growth. If registered, benzovindiflupyr could serve as an alternative to manage CCR in Florida.
\end{abstract} treatments were compared with the most common fungicides used for
Keywords: fungi, small fruits, disease management, chemical
Florida is the second largest strawberry producer in the United States with a harvested area of approximately 4,330 ha annually (USDA 2018). Every season, Florida's strawberry production is affected by major diseases, including fruit and crown rots. Colletotrichum crown rot (CCR) of strawberry, caused by Colletotrichum gloeosporioides, is an important disease for warm strawberrygrowing regions (MacKenzie et al. 2009; Peres et al. 2017). C. gloeosporioides was recently studied and reclassified as a species complex that includes three species related to strawberry: $C$. siamense, $C$. fructicola, and C. theobromicola (syn. C. fragariae) (Weir et al. 2012). Since the species causing CCR on strawberry in Florida is not known, we used C. gloeosporioides sensu lato in our study. In Florida, the primary sources of inoculum of $C$. gloeosporioides are noncultivated hosts around strawberry fields, i.e., oak trees, wild grape, and common weeds (MacKenzie et al. 2008; Xiao et al. 2004). Pathogen dispersal is favored by water, especially windy rains and overhead irrigation, which is commonly used for about 10 days after planting to aid plant establishment in Florida.

The symptoms of the disease start with plant wilting, similar to water stress, and develop until plant collapse. A vascular discoloration is observed when the crown is cut in longitudinal section (Peres et al. 2017). Such symptoms might be mistaken for those caused by Phytophthora spp. (Smith 1998) and Macrophomina phaseolina (Peres et al. 2018), and confirmation of the diagnosis should be done by pathogen identification in a laboratory.

Management of CCR in Florida relies on the use of resistant cultivars. Although there are no completely resistant cultivars to CCR, different levels of susceptibility exist among them. For instance, the two most planted cultivars in the past years ('Florida Radiance'

${ }^{\dagger}$ Corresponding author: N. A. Peres; nperes@ufl.edu

Funding: This project was partially funded by the Florida Strawberry Research and Education Foundation.

*The $\boldsymbol{e}$-Xtra logo stands for "electronic extra" and indicates that one supplementary table is published online.

The author(s) declare no conflict of interest.

Accepted for publication 18 May 2020.

(C) 2020 The American Phytopathological Society and Sweet Sensation 'Florida 127') are moderately resistant to the disease, whereas 'Strawberry Festival' and 'Florida Beauty' are susceptible (Chandler et al. 2009; Mangandi et al. 2015; Whitaker et al. 2015, 2017). Cultural practices that involve limited use of water for overhead irrigation or selection of nitrate sources of nitrogen rather than ammonium for fertilization might help suppress pathogen dispersal and disease development (Smith 2009). However, such practices might pose practical constraints on the strawberry production system. Therefore, commercial management of CCR relies on the use of fungicides. The most recent list of fungicides recommended for CCR includes captan, thiophanate-methyl, pyraclostrobin, and azoxystrobin (Whitaker et al. 2018). With the extensive use of azoxystrobin in strawberry production to manage other diseases such as anthracnose fruit rot and root necrosis (Forcelini et al. 2016), resistance of $C$. gloeosporioides to this active ingredient was reported in 2015 (Oliveira et al. 2016). Hence, it is crucial to conduct research to screen for resistance and identify alternative fungicides for CCR management.

The succinate-dehydrogenase-inhibitors (SDHIs) is a group of fungicides already used in strawberry production to manage major fruit rot diseases such as Botrytis and Anthracnose fruit rots (Amiri et al. 2019; Whitaker et al. 2018). Among the SDHIs registered for strawberry use are boscalid, penthiopyrad, fluopyram, fluxapyroxad, and isofetamid. Boscalid, for example, was registered for use in strawberry production in 2003. Soon after its registration, resistance of Botrytis cinerea and Colletotrichum spp. to boscalid and other SDHI fungicides was reported in the U.S. (Fernández-Ortuño et al. 2012; Hu et al. 2016; Ishii et al. 2016). SDHI fungicides act by inhibiting cellular respiration and their target is the mitochondrial complex II (FRAC 2019). One of the steps prior to registration of a new SDHI fungicide against a certain pathogen involves investigating the baseline sensitivity of fungal species to the new products. To determine the baseline sensitivity, one needs to calculate the effective dose of the fungicide that inhibits $50 \%$ of the fungal growth $\left(\mathrm{EC}_{50}\right)$, and this calculation may be facilitated by the use of a spiral gradient dilution assay, previously described by Förster et al. (2004).

Previous work by Ishii et al. (2016) demonstrated in vitro activity of the SDHIs against Colletotrichum species, but this work only included a single isolate from a strawberry field in Japan. Thus, there was a need to determine the efficacy of SDHI fungicides for control of CCR and the baseline sensitivity of $C$. gloeosporioides isolates from strawberry. To test our hypothesis that some of the SDHI fungicides could be effective for management of CCR in Florida, our 
objectives were to: 1 ) determine the sensitivity of $C$. gloeosporioides from Florida fields to six SDHIs in vitro, 2) determine the baseline sensitivity profile of $C$. gloeosporioides isolates to the SDHI fungicides found effective in the prior screening, i.e., benzovindiflupyr and penthiopyrad, and 3) evaluate the efficacy of five different SDHI fungicides applied pre- or postinoculation of $C$. gloeosporioides on CCR management in a field trial.

\section{Materials and Methods}

In vitro screening of SDHIs. Eighty-two isolates of $C$. gloeosporioides from strawberry were selected from the Gulf Coast Research and Education Center fungal culture collection. Isolates were recovered from symptomatic strawberry crowns from 1988 to 2018 and stored both at $-80^{\circ} \mathrm{C}$ on $30 \%$ glycerol and at $-20^{\circ} \mathrm{C}$ on sterile filter paper. To test for sensitivity to six SDHI fungicides, isolates were grown on $50 \%$ potato dextrose agar (PDA) (Oxoid, ThermoFisher Scientific, Wilmington, DE) for 5 days at $23^{\circ} \mathrm{C}$ under fluorescent light. A 4-mm diameter mycelial plug from each isolate was transferred to a Petri dish each containing PDA (Difco, Becton Dickinson \& Company, Sparks, MD) amended with a different SDHI fungicide. PDA was amended with $100 \mu \mathrm{g} / \mathrm{ml}$ of benzovindiflupyr (Aprovia, Syngenta Crop Protection, Greensboro, NC), fluopyram (Luna Privilege, Bayer Crop Science, St. Louis, MO), fluxapyroxad (Xemium, BASF, Research Triangle Park, NC), isofetamid (Kenja, Summit Agro USA, Durham, NC), penthiopyrad (Fontelis, Corteva Agriscience, Wilmington, DE), or pydiflumetofen (Miravis, Syngenta Crop Protection, Greensboro, NC). The concentration of SDHI fungicide amended to the medium and methodology for evaluation of $C$. gloeosporioides sensitivity was previously determined by Ishii et al. (2016). Mycelial growth of the isolates was evaluated after 4 days and compared with a nonamended control plate. An isolate was considered resistant if its mycelia grew at $100 \mu \mathrm{g} / \mathrm{ml}$. One plate per isolate/fungicide was used and the assay was repeated once.

Baseline and fungicide sensitivity assay. The initial screening of SDHI fungicides showed that only benzovindiflupyr and penthiopyrad were effective for in vitro control of $C$. gloeosporioides at $100 \mu \mathrm{g} / \mathrm{ml}$. Therefore, we determined the baseline and fungicide sensitivity of strawberry isolates that were collected before and after the introduction of these SDHI fungicides. $\mathrm{EC}_{50} \mathrm{~s}$ were determined by mycelial growth assays using the spiral gradient dilution (SGD) method as described by Förster et al. (2004).

One hundred $C$. gloeosporioides isolates from strawberry were selected from the fungal culture collection at the Gulf Coast Research and Education Center and separated into two groups: nonexposed to SDHI fungicides (collected before 2003, $n=42$ ) and exposed to SDHI fungicides (collected after 2003, $n=58$ ). The isolates were grown on $50 \%$ PDA for 7 days at $23^{\circ} \mathrm{C}$ until full sporulation. For each isolate, $1 \mathrm{ml}$ of spore suspension of $10^{5} \mathrm{conidia} / \mathrm{ml}$ was prepared and evenly spread onto a $15-\mathrm{cm}$ diameter Petri dish containing $45 \mathrm{ml}$ of $\mathrm{PDAA}^{+}$medium ( $39 \mathrm{~g}$ PDA $+7 \mathrm{~g}$ agar per liter). The plates were incubated for 2 days at $23^{\circ} \mathrm{C}$ under constant fluorescent light. Using an agar slicer designed by Amiri et al. (2013), mycelial strips were cut and transferred to a new plate containing PDA amended with fungicide, placing the strip across the fungicide gradient. Two strips for each isolate were used on three different plates. The stock suspension or solution concentration for each fungicide was calculated using the spiral gradient endpoint (SGE) software (Spiral System, Autoplate 4000; Spiral Biotech) and was $185.32 \mu \mathrm{g} / \mathrm{ml}$ for benzovindiflupyr and $1,789.96 \mu \mathrm{g} / \mathrm{ml}$ for penthiopyrad. PDA was amended with fungicides using the Spiral System Autoplate 4000 (Spiral Biotech) and the final range of concentrations were 0.01 to $1 \mu \mathrm{g} / \mathrm{ml}$ for benzovindiflupyr and 0.1 to $10 \mu \mathrm{g} / \mathrm{ml}$ for penthiopyrad.

After 3 days, the mycelial growth of the control plate containing nonamended PDA was measured and divided by two. The value corresponding to $50 \%$ growth of the isolate was marked on the fungicide plate. The distance between the $50 \%$ growth and the center of the plate was measured and that number was used in the SGE software to calculate the $\mathrm{EC}_{50}$. Data were tabulated and histograms were created for each fungicide using Excel spreadsheets and general formulas to determine data range, number of class interval, and interval class width. The experiment was conducted twice. The least square means $\mathrm{EC}_{50}$ values of each isolate were determined by analyzing the data in a mixed model using the statistical software SAS (Procedure PROC MIXED) (SAS Institute, Cary, NC). The model was constructed using $\mathrm{EC}_{50}$ values as response variable, 'isolates' as fixed, and 'experiment' and 'repetition' as random variables, respectively. The least square means $\mathrm{EC}_{50}$ values are presented in the supplementary table of this manuscript.

Field assay. Two experiments were conducted in the 2017-18 and 2018-19 strawberry seasons to evaluate the efficacy of SDHI fungicides for CCR management. Strawberry transplants of 'Strawberry Festival' were obtained from a California nursery. Field experiments were planted in mid-October in both years, in raised beds covered with black plastic mulch. Strawberry transplants were planted in two staggered rows in a 20-plant plot and spaced $38 \mathrm{~cm}$ within and between rows. Gaps of $76 \mathrm{~cm}$ without plants were left between plots. Overhead irrigation was provided for 10 days after planting to facilitate plant establishment and further irrigation and fertilization were delivered via a single drip tape located in the center of the bed.

On 15 November 2017 and 2018, the plants were inoculated with a mixture of four C. gloeosporioides isolates pathogenic to strawberry, 97-15A, 95-63A, 98-285 (MacKenzie et al. 2006), and 16-128. The isolates were grown for 7 days as described above, and a spore suspension at $2 \times 10^{5} \mathrm{conidia} / \mathrm{ml}$ was prepared by scraping the conidia from the colony and suspending them in deionized water. Final volume was adjusted by calculating about $5 \mathrm{ml}$ of spore suspension per inoculated plant, which was foliar applied to each plant using a $\mathrm{CO}_{2}$ pressurized backpack sprayer mounted with a single nozzle and operating at 6.9 kpa of pressure. Strawberry plants were treated with fungicides either 2 days before inoculation (DBI) or 1 day after inoculation (DAI). Treatments are listed in Table 1 and consisted of 12 fungicide treatments in 2017-18, 16 fungicide treatments in 2018-19, one noninoculated control (CNI), and one inoculated control (CI). SDHI treatments were compared with the most common fungicides used for CCR management, i.e., thiophanate-methyl, pyraclostrobin, and captan. Omega (a.i. fluazinam), a fungicide of the FRAC group 29 not yet registered for strawberry production, was also included in our field trial for comparison.

Plant wilt and mortality was evaluated once a week for 18 weeks after inoculation by counting the number or symptomatic plants. Wilting plants were sampled four times during the evaluation period to confirm infection by C. gloeosporioides. Data of plant mortality was analyzed at 11 weeks after inoculation, when the noninoculated control started showing CCR symptoms. Plant mortality data were used to calculate area under disease progress curve (AUDPC), treatments were compared and means separated by Fisher's Protected LSD test $(\alpha=0.05)$ using the statistical software SAS.

\section{Results}

In vitro screening of SDHIs. All C. gloeosporioides isolates from strawberry were insensitive (naturally resistant) to fluopyram, fluxapyroxad, isofetamid, and pydiflumetofen at $100 \mu \mathrm{g} / \mathrm{ml}$ (Table 2). The SDHIs benzovindiflupyr and penthiopyrad, at $100 \mu \mathrm{g} / \mathrm{ml}$, completely inhibited the mycelial growth of $C$. gloeosporioides isolates. Inhibition of mycelial growth on PDA amended with fluopyram varied from 18.2 to $30.3 \%$, with fluxapyroxad varied from 48.6 to $67.5 \%$, with isofetamid from 29.5 to $41.8 \%$, and with pydiflumetofen from 31 to $49.1 \%$. The inhibition was similar for all the isolates independent of fungal species or year collected.

Baseline and fungicide sensitivity assay. The $\mathrm{EC}_{50}$ of $C$. gloeosporioides isolates nonexposed to SDHI fungicides $(n=42)$ varied from 0.08 to $1.11 \mu \mathrm{g} / \mathrm{ml}$ on benzovindiflupyr (Fig. 1A) and from 0.45 to $3.17 \mu \mathrm{g} / \mathrm{ml}$ on penthiopyrad amended media (Fig. 1C). $C$. gloeosporioides isolates exposed to SDHI fungicides $(n=58)$ had $\mathrm{EC}_{50} \mathrm{~s}$ varying from 0.08 to $0.70 \mu \mathrm{g} / \mathrm{ml}$ when treated with benzovindiflupyr (Fig. 1B), and from 0.70 to $3.06 \mu \mathrm{g} / \mathrm{ml}$ when treated with penthiopyrad (Fig. 1D). For both fungicides, the histogram of $C$. gloeosporioides $\mathrm{EC}_{50} \mathrm{~S}$ was skewed left, meaning that most of the isolates were grouped at the lower ranges of $\mathrm{EC}_{50}$ (Fig. 1). For benzovindiflupyr, most of the isolates independent of exposure to SDHIs had $\mathrm{EC}_{50 \mathrm{~s}}$ between 0.15 and $0.40 \mu \mathrm{g} / \mathrm{ml}$, whereas only one isolate had an $\mathrm{EC}_{50}$ higher than $0.8 \mu \mathrm{g} / \mathrm{ml}$ (Fig. 1). In contrast, 
for penthiopyrad, more than $90 \%$ of the exposed isolates had an $\mathrm{EC}_{50}$ higher than $1.02 \mu \mathrm{g} / \mathrm{ml}(n=50$, Fig. 1D), whereas most of the nonexposed isolates had $\mathrm{EC}_{50} \mathrm{~s}$ between 0.45 and $1.29 \mu \mathrm{g} / \mathrm{ml}(n=31$, Fig. 1C). Fourteen $C$. gloeosporioides isolates nonexposed to penthiopyrad had an $\mathrm{EC}_{50}$ to penthiopyrad between 0.45 and $0.87 \mu \mathrm{g} / \mathrm{ml}$ and 20 exposed isolates had $\mathrm{EC}_{50} \mathrm{~s}$ between 1.02 and $1.33 \mu \mathrm{g} / \mathrm{ml}$. The highest $\mathrm{EC}_{50}$ to penthiopyrad was $3.17 \mu \mathrm{g} / \mathrm{ml}$ from a $C$. gloeosporioides isolate collected in 1998 whereas the highest $\mathrm{EC}_{50}$ to benzovindiflupyr was $1.11 \mu \mathrm{g} / \mathrm{ml}$ from an isolate collected in 2001 (Supplementary Table).

Field assay. In both seasons, we observed the greatest differences between treatments at 11 weeks after inoculation (Table 1). In the 2018-19 season, after 11 weeks of evaluation, plants from the CNI started to show disease symptoms (Fig. 2). The first symptoms of plant wilt and mortality were observed within 2 weeks after inoculation and increased until the last evaluation at 18 weeks after inoculation.

In 2017-18, benzovindiflupyr applied 1 DAI and captan and fluazinam applied $2 \mathrm{DBI}$ were the best treatments for reducing plant mortality compared with the controls ( $P \leq 0.0002$; Table 1$)$. In 2018-19, fluazinam and benzovindiflupyr applied either 1 DAI or 2 DBI, pyraclostrobin applied 1 DAI, and captan applied 2 DBI were the best treatments for reducing plant mortality $(P \leq 0.0003)$. Captan was able to reduce plant mortality by 21 to $22 \%$ in both seasons, demonstrating it to be a good protectant fungicide. The SDHI fungicides fluopyram, isofetamid, and pydiflumetofen were not effective for CCR management. Strawberry plants treated with these three SDHIs had over $46 \%$ mortality in the first season and over $23 \%$ mortality in 2018-19. Mortality in the treatment with thiophanate-methyl, a fungicide currently used for CCR management, was not significantly different from the inoculated control. Penthiopyrad was not effective for CCR management in the 2017-18 season but had some effectiveness in 2018-19 when applied 1 DAI.

AUDPC in the 2017-18 season was higher than in 2018-19 (Table 1). For the inoculated control, the AUDPC was 9.86 in 2017-18 and 7.32 in 2018-19, after 11 weeks of evaluation. Mean separation for AUDPC showed that in 2017-18, fluazinam applied 2 DBI and benzovindiflupyr applied 1 DAI were the most effective fungicides for reducing the progress of the disease $(P \leq 0.0001)$. In 2018-19, the most effective fungicides for reducing CCR progress were the same as those that reduced plant mortality, plus penthiopyrad $(P \leq 0.0014)$.

\section{Discussion}

This study demonstrates the efficacy of the SDHI fungicide benzovindiflupyr for inhibiting $C$. gloeosporioides and managing Colletotrichum crown rot of strawberry in the field. To our knowledge, this is the first study of fungicide sensitivity of $C$. gloeosporioides from strawberry before and after exposure to SDHI fungicides in the U.S.

Table 1. Plant mortality and area under the disease progress curve (AUDPC) of fungicide treatments applied for the management of Colletotrichum crown rot (CCR) of strawberry in Florida during the 2017-18 and 2018-19 seasons

\begin{tabular}{|c|c|c|c|c|c|c|c|}
\hline \multirow{2}{*}{ Time of application ${ }^{w}$} & \multirow{2}{*}{\multicolumn{3}{|c|}{ 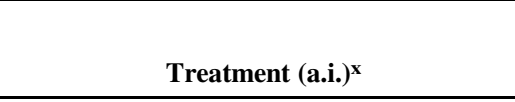 }} & \multicolumn{2}{|c|}{ 2017-18 } & \multicolumn{2}{|c|}{ 2018-19 } \\
\hline & & & & $\%$ Plant mortality ${ }^{y}$ & AUDPC & $\%$ Plant mortality & AUDPC \\
\hline \multirow[t]{8}{*}{2 days before inoculation } & \multicolumn{3}{|c|}{ Aprovia (benzovindiflupyr) } & 37.5 bcde & 6.82 defg & 9.0 cde & $1.35 \mathrm{~cd}$ \\
\hline & \multicolumn{3}{|c|}{ Captan (captan) } & $20.0 \mathrm{def}$ & 3.50 efg & $7.8 \mathrm{de}$ & $1.97 \mathrm{bcd}$ \\
\hline & \multicolumn{3}{|c|}{ Fontelis (penthiopyrad) } & $40.0 \mathrm{abcd}$ & $11.37 \mathrm{abcd}$ & $27.0 \mathrm{abc}$ & $6.52 \mathrm{ab}$ \\
\hline & \multicolumn{3}{|c|}{ Kenja (isofetamid) } & $52.5 \mathrm{ab}$ & $13.82 \mathrm{abc}$ & $30.0 \mathrm{ab}$ & $5.60 \mathrm{abc}$ \\
\hline & \multicolumn{3}{|c|}{ Luna Tranquility (fluopyram+pyrimethanil) } & $48.8 \mathrm{abc}$ & $13.56 \mathrm{abc}$ & $36.8 \mathrm{a}$ & $9.37 \mathrm{a}$ \\
\hline & \multicolumn{3}{|c|}{ Miravis (pydiflumetofen) } & - & - & $24.0 \mathrm{abcd}$ & $4.87 \mathrm{abcd}$ \\
\hline & \multicolumn{3}{|c|}{ Omega (fluazinam) } & $21.3 \mathrm{def}$ & $3.06 \mathrm{fg}$ & $6.3 \mathrm{de}$ & $2.23 \mathrm{bcd}$ \\
\hline & \multicolumn{3}{|c|}{ Topsin (thiophanate-methyl) } & - & - & $23.0 \mathrm{abcd}$ & $5.53 \mathrm{abc}$ \\
\hline \multirow[t]{8}{*}{1 day after inoculation } & \multicolumn{3}{|c|}{ Aprovia (benzovindiflupyr) } & $16.3 \mathrm{ef}$ & $2.19 \mathrm{~g}$ & $6.5 \mathrm{de}$ & $2.15 \mathrm{bcd}$ \\
\hline & \multicolumn{3}{|c|}{ Cabrio (pyraclostrobin) } & $27.5 \mathrm{cde}$ & $5.77 \mathrm{defg}$ & $7.5 \mathrm{de}$ & $1.40 \mathrm{~cd}$ \\
\hline & \multicolumn{3}{|c|}{ Fontelis (penthiopyrad) } & 33.8 bcde & 8.84 cdef & 11.5 bcde & $2.26 \mathrm{bcd}$ \\
\hline & \multicolumn{3}{|c|}{ Kenja (isofetamid) } & $60.0 \mathrm{a}$ & $17.67 \mathrm{a}$ & $28.3 \mathrm{ab}$ & $5.41 \mathrm{abc}$ \\
\hline & \multicolumn{3}{|c|}{ Luna Tranquility (fluopyram+pyrimethanil) } & $46.3 \mathrm{abc}$ & $11.64 \mathrm{abcd}$ & $23.8 \mathrm{abcd}$ & $6.60 \mathrm{ab}$ \\
\hline & \multicolumn{3}{|c|}{ Miravis (pydiflumetofen) } & - & - & $38.8 \mathrm{a}$ & $9.36 \mathrm{a}$ \\
\hline & \multicolumn{3}{|c|}{ Omega (fluazinam) } & - & - & $6.3 \mathrm{de}$ & $0.96 \mathrm{~cd}$ \\
\hline & \multicolumn{3}{|c|}{ Topsin (thiophanate-methyl) } & $55.0 \mathrm{ab}$ & $16.36 \mathrm{ab}$ & $36.0 \mathrm{a}$ & $8.87 \mathrm{a}$ \\
\hline N.A. & \multicolumn{3}{|c|}{ Control noninoculated } & $5.0 \mathrm{f}$ & $1.21 \mathrm{~g}$ & $1.3 \mathrm{e}$ & $0.26 \mathrm{~d}$ \\
\hline \multirow{2}{*}{ N.A. } & \multicolumn{3}{|c|}{ Control inoculated } & $42.0 \mathrm{abcd}$ & 9.86 bcde & $28.8 \mathrm{ab}$ & $7.32 \mathrm{a}$ \\
\hline & \multicolumn{3}{|c|}{ Probability of a greater $\mathrm{F}$ value ${ }^{\mathrm{z}}$} & 0.0002 & $<0.0001$ & 0.0003 & 0.0014 \\
\hline \multicolumn{8}{|c|}{$\begin{array}{l}\text { wime of application refers to the timing during which plants were sprayed with the respective fungicide treatments relative to pathogen inoculation. } \\
\mathrm{x} \text { Treatment refers to the brand name and active ingredient of the fungicides tested for CCR management. } \\
\text { y Percent plant mortality evaluated } 11 \text { weeks after inoculation was calculated using the proportion of dead plants relative to the total number of plants for each } \\
\text { treatment. } \\
\text { z Probability of a greater F value refers to the probability value for the effect of treatment on plant mortality and AUDPC. }\end{array}$} \\
\hline \multirow[b]{2}{*}{ Year collected ${ }^{y}$} & & & & Mycelial grov & ibition $(\%)$ & & \\
\hline & $r$ of isolates & Fluopyram & Isofetamid & Penthiopyrad & pyroxad & Pydiflumetofen & $\overline{\text { vindiflupyr }}$ \\
\hline 1988 & 1 & 19.9 & 29.5 & 100.0 & 67.5 & 38.8 & 100.0 \\
\hline 1995 & 5 & 18.2 & 32.4 & 100.0 & 48.6 & 36.4 & 100.0 \\
\hline 1996 & 11 & 26.3 & 38.9 & 100.0 & 49.5 & 42.3 & 100.0 \\
\hline 1997 & 8 & 24.5 & 35.6 & 100.0 & 50.7 & 41.2 & 100.0 \\
\hline 1998 & 2 & 24.9 & 40.4 & 100.0 & 54.7 & 43.7 & 100.0 \\
\hline 1999 & 3 & 29.1 & 35.5 & 100.0 & 50.0 & 49.1 & 100.0 \\
\hline 2000 & 4 & 30.3 & 41.8 & 100.0 & 54.0 & 31.0 & 100.0 \\
\hline 2001 & 2 & 18.7 & 30.7 & 100.0 & 50.8 & 31.0 & 100.0 \\
\hline 2017 & 46 & 23.2 & 34.3 & 100.0 & 49.5 & 38.8 & 100.0 \\
\hline
\end{tabular}

y Year in which isolates of Colletotrichum were collected from strawberry fields.

${ }^{\mathrm{z}}$ Mycelial growth was evaluated in potato dextrose agar amended with fungicides at $100 \mu \mathrm{g} / \mathrm{ml}$ and compared with nonamended control. 
Currently, benzovindiflupyr is not labeled for strawberry. None of the registered SDHI fungicides were effective in controlling the disease.

We tested the in vitro efficacy of fluopyram, isofetamid, penthiopyrad, fluxapyroxad, pydiflumetofen, and benzovindiflupyr at $100 \mu \mathrm{g} / \mathrm{ml}$ for inhibiting mycelial growth of $C$. gloeosporioides. Benzovindiflupyr and penthiopyrad completely inhibited mycelial growth, whereas the other SDHIs showed partial inhibition. Fluxapyroxad, one of the most recent SDHIs released for strawberry use, inhibited mycelial growth by about $50 \%$. The use of products containing fluxapyroxad as an active ingredient, e.g., Merivon, a premixture of fluxapyroxad and the QoI fungicide pyraclostrobin, might further reduce pathogen growth and disease development due to the additive effect of both compounds, but this fungicide combination was not included in our trials. Previous work with Botrytis cinerea from strawberry (Amiri et al. 2014) reported a high correlation between resistance to fluxapyroxad and penthiopyrad; in our work, we did not observe such a correlation between these two SDHIs. Penthiopyrad completely inhibited C. gloeosporioides mycelial growth at $100 \mu \mathrm{g} / \mathrm{ml}$, whereas fluxapyroxad did not.

Pydiflumetofen, the most recent SDHI registered for strawberry production, was not effective against $C$. gloeosporioides in vitro or under field conditions. In previous work with $C$. acutatum (Haack et al. 2018), pydiflumetofen did not inhibit mycelial growth at concentrations of up to $80 \mu \mathrm{g} / \mathrm{ml}$, similar to our results with C. gloeosporioides. Even though pydiflumetofen had little to no efficacy against CCR, it is registered for strawberry production in a mixture with fludioxonil (Miravis Prime) due to its efficacy against Botrytis fruit rot (Cordova et al. 2019). In screening of 30 of our $C$. gloeosporioides isolates to fludioxonil at $100 \mu \mathrm{g} / \mathrm{ml}$, mycelial growth was inhibited by 62.9 to $82.3 \%$. However, none of the isolates was completely inhibited by fludioxonil (data not shown).

Before registration of a new fungicide against a certain pathogen, the baseline sensitivity of a diverse collection of isolates must be determined by calculating their $\mathrm{EC}_{50}$ values. Most of the $C$. gloeosporioides isolates had $\mathrm{EC}_{50} \mathrm{~s}$ to benzovindiflupyr between 0.16 and $0.44 \mu \mathrm{g} / \mathrm{ml}$, and only one isolate collected in 2001 had an $\mathrm{EC}_{50}$ higher than $1.0 \mu \mathrm{g} / \mathrm{ml}$. This variation seems to occur naturally in Colletotrichum spp. isolates. The fact that the $\mathrm{EC}_{50}$ of $C$. gloeosporioides isolates is higher for penthiopyrad than for benzovindiflupyr indicated that the latter might work better for CCR management. This was confirmed in our 2017-18 season field trial, but no significant differences were observed between the two fungicides in the 2018-19 season.

In our field trial, we evaluated the efficacy of SDHIs as protectant or curative fungicides for CCR management. Benzovindiflupyr applied 1 day after inoculation of $C$. gloeosporioides was the best among the SDHI treatments. Data for the field experiments were analyzed at 11 weeks after inoculation, when the noninoculated control started showing CCR symptoms indicating that the pathogen was likely spreading to the neighboring plots.

CCR development was faster during 2017-18 than in the 2018-19 season. That might be because the temperature from inoculation time until the next morning ranged from 15 to $25^{\circ} \mathrm{C}$ in 2017 , whereas in

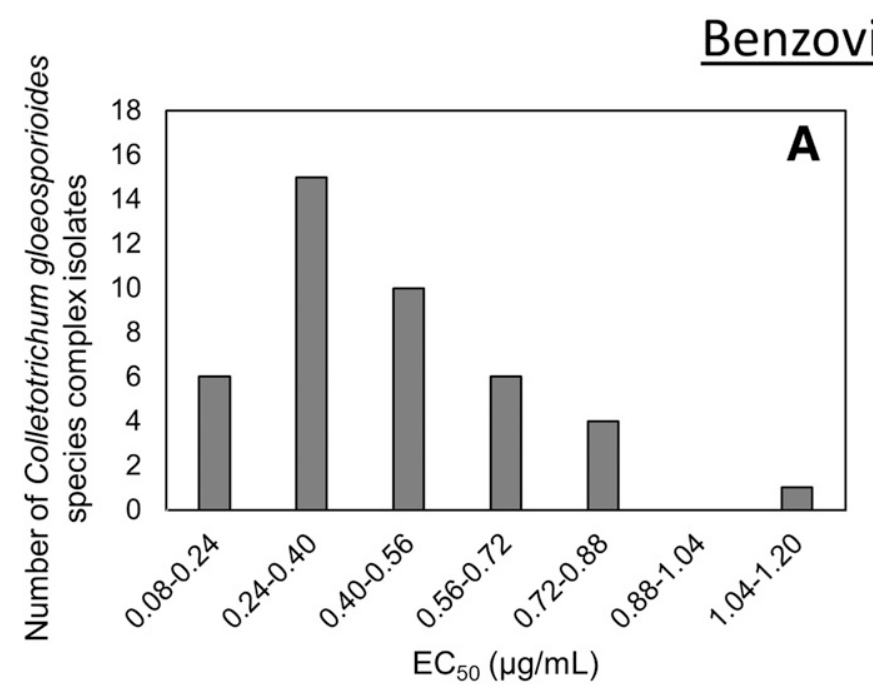

\section{indiflupyr}

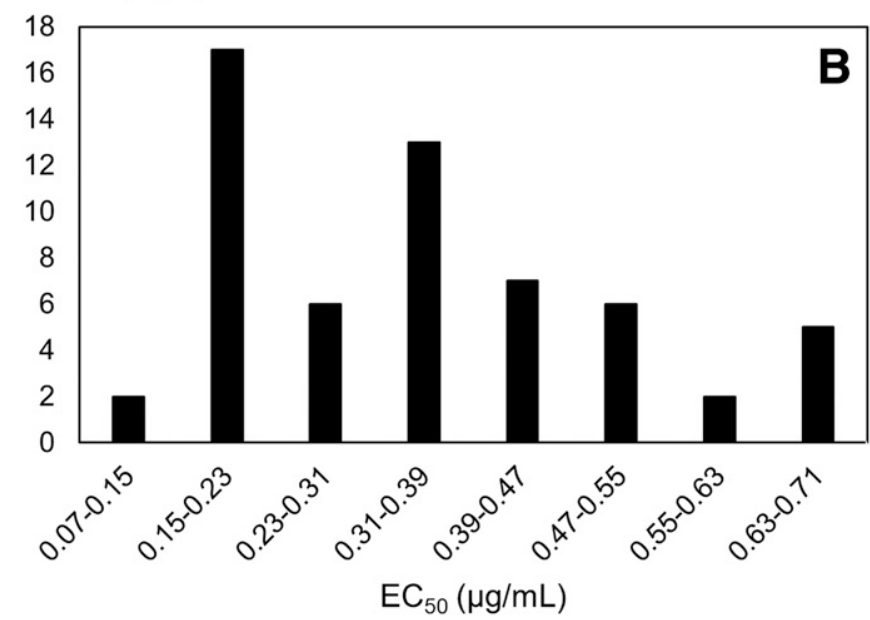

\section{Penthiopyrad}
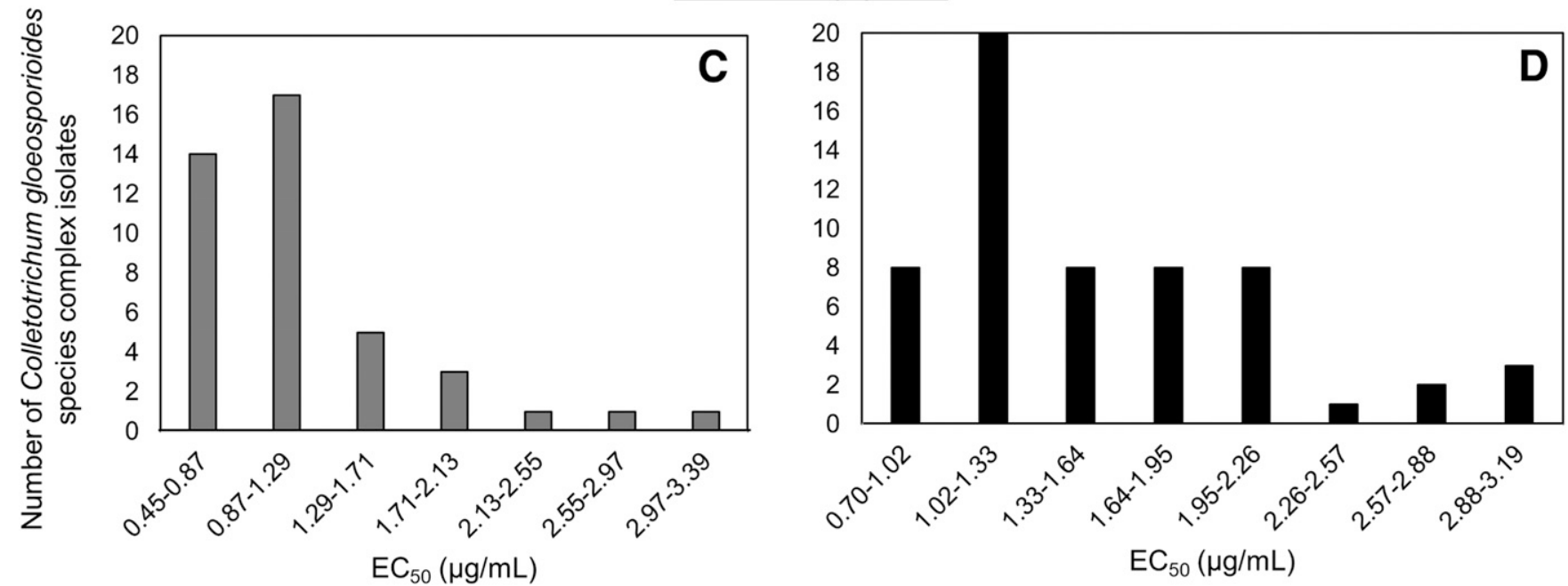

Fig. 1. Distribution of the concentration of benzovindiflupyr ( $\mathbf{A}$ and $\mathbf{B})$ and penthiopyrad $(\mathbf{C}$ and $\mathbf{D})$ needed to inhibit $50 \%\left(\mathrm{EC}_{50}\right)$ of mycelial growth of Colletotrichum gloeosporioides isolates from strawberry collected before $(\mathbf{A}$ and $\mathbf{C})$ and after $(\mathbf{B}$ and $\mathbf{D})$ exposure to $\mathrm{SDHI}$ fungicides. 
2018 the temperature ranged from 8 to $20^{\circ} \mathrm{C}$ (FAWN 2019). The colder temperatures might have slowed down $C$. gloeosporioides infection and colonization, and consequent CCR symptom development. The slower disease development might also explain the fact that more fungicides were found to be effective in the 2018-19 season, including no difference between applying benzovindiflupyr applied before or after inoculation.

Another product added to our field trial, Omega (a.i. fluazinam), was effective against CCR in both seasons. A special request has been submitted for its registration for strawberry nursery use. With the alarming situation of fungicide-resistant pathogens coming with nursery transplants (Forcelini and Peres 2018; Oliveira et al. 2017), it is important to search for different fungicides to be used in nursery and fruit production systems to avoid overuse of the same active ingredients.

SDHI fungicides, such as boscalid, have been available for the management of Botrytis fruit rot, caused by Botrytis cinerea, on Florida strawberry production since 2003 , but resistance has become widespread (Amiri et al. 2014; Zuniga et al. 2020). Other SDHIs also
2017-2018
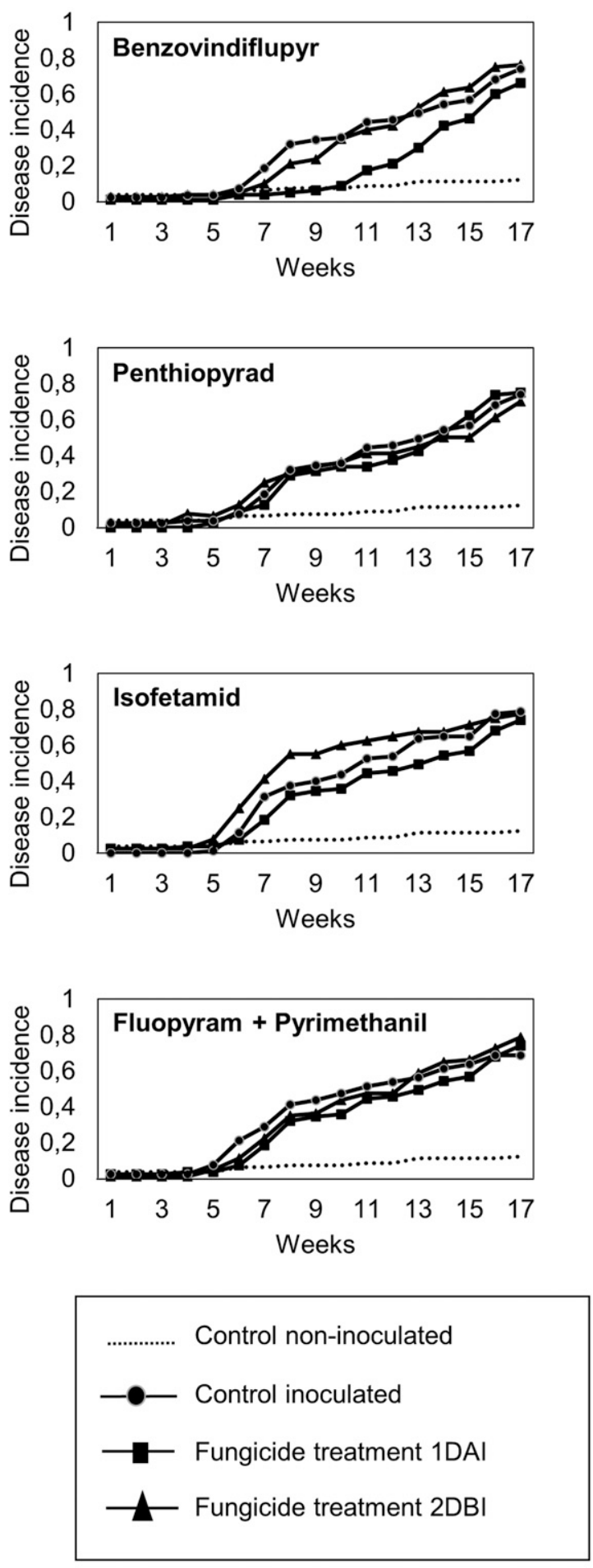

2018-2019
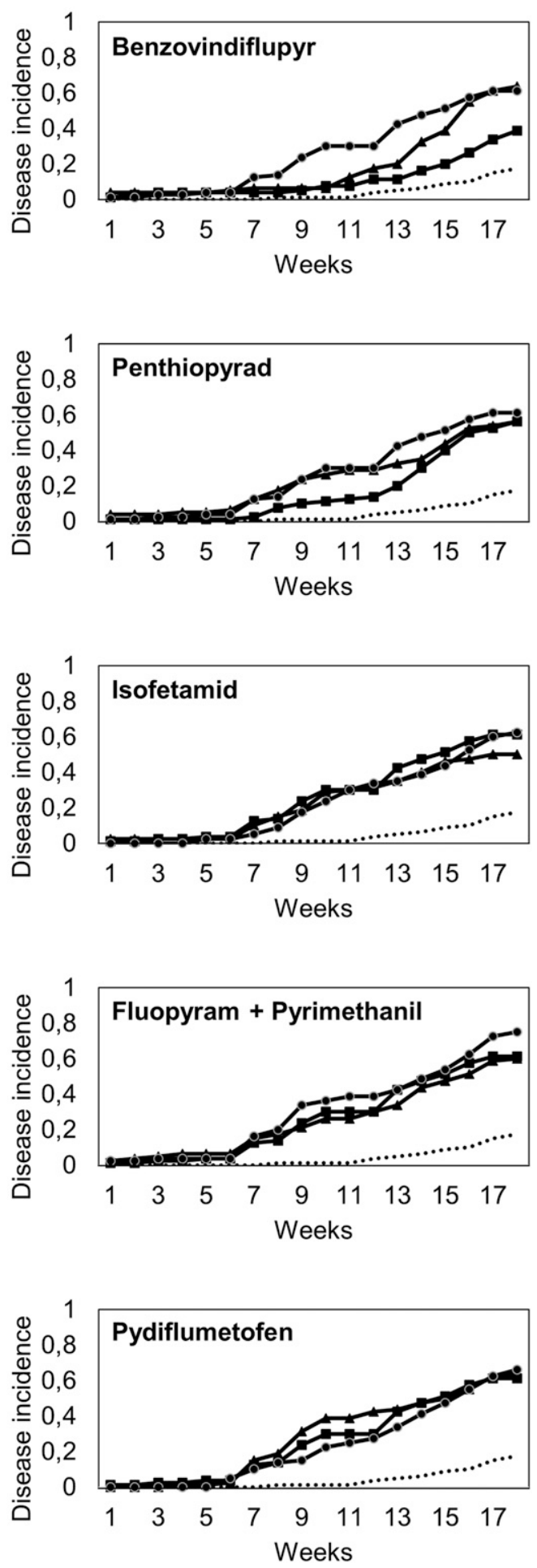

Fig. 2. Colletotrichum crown rot incidence of strawberry treated with succinate-dehydrogenase-inhibitor (SDHI) fungicides 2 days before inoculation (DBI) and 1 day after inoculation (DAI) with Colletotrichum gloeosporioides during the 2017-18 and 2018-19 seasons. 
registered for strawberry use are penthiopyrad, fluopyram, fluxapyroxad, and isofetamid (Whitaker et al. 2018). However, none of them was ever recommended for CCR in Florida. We screened C. gloeosporioides isolates from strawberry to SDHI fungicides and found natural resistance to fluopyram, fluxapyroxad, isofetamid, and pydiflumetofen. A previous study by Ishii et al. (2016) also found natural resistance of $C$. gloeosporioides from apple, grapevine, strawberry, and peach to boscalid, fluxapyroxad, and fluopyram. We did not test the sensitivity of our isolates to boscalid but would expect that our isolates would have had the same natural resistance as reported by Ishii et al. (2016).

SDHI fungicides are categorized as fungicides with medium to high risk of resistance development (FRAC 2019). Different levels of resistance to the SDHI fungicides might be conferred by at least eight known mutations in the $s d h B$ mitochondrial gene. Previous studies found the mutations H272R, H272Y, H272L, P225F, and N230I in B. cinerea from strawberry (Amiri et al. 2014; FernándezOrtuño et al. 2017; Hu et al. 2016; Zuniga et al. 2020). However, Ishii et al. (2016) sequenced the $s d h B, s d h C$, and part of $s d h D$ genes of Colletotrichum spp. and did not find mutations causing resistance to SDHI fungicides, describing it as natural resistance or insensitivity. In our study, we observed the same natural resistance reported by Ishii et al. (2016), but the $s d h B$ gene was not sequenced.

In summary, $C$. gloeosporioides from strawberry appear to have natural resistance (insensitivity) to some SDHI fungicides such as fluopyram, fluxapyroxad, isofetamid, and pydiflumetofen. Penthiopyrad inhibited mycelial growth of $C$. gloeosporioides in vitro but was not as effective in reducing CCR development on strawberry plants. The most effective SDHI fungicide for CCR management was benzovindiflupyr and strawberry growers would benefit from its registration. Fluazinam was also highly effective against CCR and could serve as a good disease management alternative for nursery growers. With the low number of fungicides available for CCR management on strawberry and the risk of fungicide resistance selection, further studies with other alternative fungicides are still necessary.

\section{Acknowledgments}

We thank Andre Gama, Paulo Mello, and Robert Martin for technical assistance.

\section{Literature Cited}

Amiri, A., Heath, S. M., and Peres, N. A. 2013. Phenotypic characterization of multifungicide resistance in Botrytis cinerea isolates from strawberry fields in Florida. Plant Dis. 97:393-401.

Amiri, A., Heath, S. M., and Peres, N. A. 2014. Resistance to fluopyram, fluxapyroxad, and penthiopyrad in Botrytis cinerea from strawberry. Plant Dis. 98:532-539.

Amiri, A., Zuniga, A. I., Cordova, L. G., and Peres, N. A. 2019. The importance of selecting appropriate rotation and tank-mix partners for novel SDHIs to enhance botrytis fruit rot control in strawberry. Plant Dis. 103:729-736.

Chandler, C. K., Santos, B. M., Peres, N. A., Jouquand, C., Plotto, A., and Sims, C. A. 2009. 'Florida Radiance' strawberry. HortScience 44:1769-1770.

Cordova, L., Zuniga, A., Mertely, J., and Peres, N. 2019. Evaluation of fungicide products to control Botrytis fruit rot in annual strawberry, 2018-19. Plant Dis. Manag. Rep. 13:PF077.

FAWN. 2019. Florida Automated Weather Network - Report Generator. Page Summary of recent data from the FAWN archived weather data. University of Florida, https://fawn.ifas.ufl.edu/data/reports/.

Fernández-Ortuño, D., Chen, F. P., and Schnabel, G. 2012. Resistance to pyraclostrobin and boscalid in Botrytis cinerea isolates from strawberry fields in the Carolinas. Plant Dis. 96:1198-1203.

Fernández-Ortuño, D., Pérez-García, A., Chamorro, M., de la Peña, E., de Vicente, A., and Torés, J. A. 2017. Resistance to the SDHI fungicides boscalid, fluopyram, fluxapyroxad, and penthiopyrad in Botrytis cinerea from commercial strawberry fields in Spain. Plant Dis. 101:1306-1313.
Forcelini, B. B., and Peres, N. A. 2018. Widespread resistance to QoI fungicides of Colletotrichum acutatum from strawberry nurseries and production fields. Plant Health Prog. 19:338-341.

Forcelini, B. B., Seijo, T. E., Amiri, A., and Peres, N. A. 2016. Resistance in strawberry isolates of Colletotrichum acutatum from Florida to quinoneoutside inhibitor fungicides. Plant Dis. 100:2050-2056.

Förster, H., Kanetis, L., and Adaskaveg, J. E. 2004. Spiral gradient dilution, a rapid method for determining growth responses and $50 \%$ effective concentration values in fungus-fungicide interactions. Phytopathology 94:163-170.

FRAC. 2019. FRAC Code List 2019: Fungal control agents sorted by cross resistance pattern and mode of action (including FRAC Code numbering). CropLife International, Brussels, Belgium.

Haack, S. E., Ivors, K. L., Holmes, G. J., Förster, H., and Adaskaveg, J. E. 2018. Natamycin, a new biofungicide for managing crown rot of strawberry caused by QoI-resistant Colletotrichum acutatum. Plant Dis. 102:1687-1695.

Hu, M.-J., Fernández-Ortuño, D., and Schnabel, G. 2016. Monitoring resistance to SDHI fungicides in Botrytis cinerea from strawberry fields. Plant Dis. 100: 959-965.

Ishii, H., Zhen, F., Hu, M. J., Li, X. P., and Schnabel, G. 2016. Efficacy of SDHI fungicides, including benzovindiflupyr, against Colletotrichum species. Pest Manag. Sci. 72:1844-1853

MacKenzie, S., Mertely, J., Seijo, T., and Peres, N. 2008. Colletotrichum fragariae is a pathogen on hosts other than strawberry. Plant Dis. 92:1432-1438.

MacKenzie, S. J., Legard, D. E., Timmer, L. W., Chandler, C. K., and Peres, N. A. 2006. Resistance of strawberry cultivars to crown rot caused by Colletotrichum gloeosporioides isolates from Florida is nonspecific. Plant Dis. 90:1091-1097.

MacKenzie, S. J., Mertely, J. C., and Peres, N. A. 2009. Curative and protectant activity of fungicides for control of crown rot of strawberry caused by Colletotrichum gloeosporioides. Plant Dis. 93:815-820.

Mangandi, J., Peres, N. A., and Whitaker, V. M. 2015. Identifying resistance to crown rot caused by Colletotrichum gloeosporioides in strawberry. Plant Dis. 99:954-961.

Oliveira, M. S., Amiri, A., Zuniga, A. I., and Peres, N. A. 2017. Sources of primary inoculum of Botrytis cinerea and their impact on fungicide resistance development in commercial strawberry fields. Plant Dis. 101:1761-1768.

Oliveira, M. S., Chamorro, M., and Peres, N. A. 2016. Resistance of Colletotrichum gloeosporioides from strawberry to azoxystrobin and reduced-sensitivity to thiophanate-methyl. Phytopathology 106:72-73.

Peres, N. A., Baggio, J. S., and Mertely, J. C. 2018. Charcoal rot of strawberries caused by Macrophomina phaseolina. Electronic Data Information Source University of Florida (UF/IFAS), https://edis.ifas.ufl.edu/pp161.

Peres, N. A., Oliveira, M. S., and MacKenzie, S. J. 2017. Colletotrichum Crown Rot (Anthracnose Crown Rot) of Strawberries. Electronic Data Information Source UF/IFAS, http://edis.ifas.ufl.edu/pp156.

Smith, B. J. 1998. Anthracnose crown rot. Pages 46-48 in: Compendium of Strawberry Diseases. J. L. Maas, ed. The American Phytopathological Society, St. Paul, MN.

Smith, B. J. 2009. Nitrogen fertilizer affects the severity of anthracnose crown rot disease of greenhouse grown strawberries. Plant Health Prog. 10:16.

USDA. 2018. Pages V34-V35 in: Statistics of fruits, tree nuts, and horticultural specialties. United States Department of Agriculture, National Agricultural Statistics Service, Washington, DC

Weir, B. S., Johnston, P. R., and Damm, U. 2012. The Colletotrichum gloeosporioides species complex. Stud. Mycol. 73:115-180.

Whitaker, V. M., Boyd, N. S., Peres, N. A., Noling, J. W., and Renkema, J. 2018 Strawberry production. Pages 311-332 in: Vegetable Production Handbook of Florida. G. E. Vallad, H. A. Smith, P. J. Dittmar, and J. H. Freeman, eds University of Florida-IFAS Extension, Gainesville, FL.

Whitaker, V. M., Chandler, C. K., Peres, N., do Nascimento Nunes, M. C., Plotto, A., and Sims, C. A. 2015. Sensation ${ }^{\mathrm{TM}}$ 'Florida127' strawberry. HortScience 50:1088-1091.

Whitaker, V. M., Osorio, L. F., Peres, N. A., Fan, Z., Herrington, M., do Nascimento Nunes, M. C., Plotto, A., and Sims, C. A. 2017. 'Florida Beauty' strawberry. HortScience 52:1443-1447.

Xiao, C. L., MacKenzie, S. J., and Legard, D. E. 2004. Genetic and pathogenic analyses of Colletotrichum gloeosporioides isolates from strawberry and noncultivated hosts. Phytopathology 94:446-453.

Zuniga, A. I., Oliveira, M. S., Suguinoshita Rebello, C., and Peres, N. A. 2020. Baseline sensitivity of Botrytis cinerea isolates from strawberry to isofetamid compared to other SDHIs. Plant Dis. 104:1224-1230. 